L, CSILLAG

I, JÅNOSSY

$V, F$, KITAEVA

$\mathrm{N}$, KROO

N.N. SOBOLEV
THE INFLUENCE OF THE FINITE SIZE OF THE LIGHT SPOT ON THE LASER INDUCED REORIENTATION OF LIQUID CRYSTALS

\title{
Hungarian Fcademy of Sciences
} CENTRAL RESEARCH

INSTITUTE FOR PHYSICS 
THE INFLUENCE OF THE FINITE SIZE OF THE LIGHT SPOT ON THE LASER INDUCED REORIENTATION OF LIQUID CRYSTALS

L. Csillag, I. Jánossy, V.F. Kitaeva ${ }^{+}$, N. Kroó, N.N. Sobolev ${ }^{+}$

Central Research Institute for Physics

H-1525 Budapest 114, P.O.B. 49, Hungary

+ Lebedev Physical Institute Moscow, USSR

Submitted to Molecular Crystals and Liquid Crystals 


\section{ABSTRACT}

The threshold intensity for the laser induced deformation of nematic liquid crystals is calculated as a function of the spot size ot the 11luminating beam. It is shown, that due to the small size of the 11 ght spot, the optical threshold is higher than that expected from the Fredericks threshold formula for static electric fields of infinite large dimension in the cell plane. Experimental data measured on a homeotrop OCB /octyl-cyano-byphenyl/ sample fit well the theoretical curve. Results obtained on the temperature and wavelength dependence of the threshold can be interpreted on the basis of the given theory.

\section{АННОТАЦИЯ}

В зависимости от размеров освещенного пятна вычислена пороговая мощность лазерного излучения, вызывающая деформацию нематических жидких кристаллов. Показано, что из-за ограниченного размера пятна оптический порог лежит выле, чем порог, полученный из формулы Фредерикса для статического электрического поля бесконечного размера в плоскости кюветы. Экспериментальные данные, полученные на гомеотропном жидком кристалле ОцБФ/октилциано-бифенил/ хорошо соответствуют теоретической кривой. На основе данной теории можно интерпретировать и зависимость порога от температуры и от длины волны излучения.

\section{KIVONAT}

A cikkben kiszâmitjuk a nematikus folyadékkristály rétegek lézerrel történố deformálásához szükséges küszöbteljesitményt a lézer foltméretének függvényében. Megmutatjuk, hogy a folt véges átmérôjének következtében az optikai küszöb magasabb, mint ami a cella sikjában végtelen kiterjedésü sztatikus elektromos tér esetében a Fredericks küszöbformulából adódna. Merôlegesen rendezett oktil-ciano-bifenilen /OCB/ végzett mérések jól illeszthetôk az elméleti görbére. A küszöb hớmérséklet- és hullámhosszfüggésére kapott eredmények is értelmezhetôk a jelen elmélettel. 


\section{INTRODUCTION}

As it was reported by us previously [1], by illuminating a nematic liquid crystalline film with a focused laser beam, an increase in the beam divergence and a ring system appearing in it can be detected. This effect could be explained as an orientational deformation due to a Fredericks transition in optical fields. It has been shown, that in analogy with the static Fredericks effect, for homeotrop cell and at normal incidence this deformation starts only above a certain threshold laser power. The focused laser light, however, has a spatial intensity distribution - in the simplest case a Gaussian distribution - with a half-width of some tens of microns which is comparable with the sample thickness. Therefore it can be expected, that the actual optical threshold value differs from that of the Fredericks transition in a static electric field with practically infinite large dimensions in the cell plane.

This problem is studied in this paper both theoretically and experimentally. First we calculate the value of the laser intensity threshold by a simplified model for the case of a homeotrop nematic cell and at normal incidence of the laser beam. Then experimental results on a nematic OCB /octyl-cyano-biphenyl/ sample are described showing that good agreement exists between the theoretically expected and the measured values. Additional measurements are also reported on the temperature and wavelength dependence of this threshold value giving a further support to our calculations.

\section{CALCULATION OF THE THRESHOLD}

We investigate a homeotropic sandwich-like cell of a nematic liquid crystal /NLC/, in which the L director is fixed uniformely at the boundaries, and which is illuminated with a linearly plarized and focused laser beam. It is assumed that the focal length of the focusing lens is large enough so that the laser beam can be considered as a parallel beam within the sample.

The light beam interacts with the molecules through its electric field $\underline{E}$. The torque $\Gamma^{\mid \mathrm{E} /}$ induced by $\underline{\mathrm{E}}$ in a nematic is then 


$$
\underline{\Gamma}^{\mid E /}=\underline{D} \times \underline{E}=\varepsilon_{0} \varepsilon_{a} \underline{E} \underline{L} / \underline{E} \times \underline{L} /
$$

where $\varepsilon_{\mathrm{a}}$ is the anisotropy of the dielectric constant; $\varepsilon_{a}=n_{e}^{2^{a}}-n_{0}^{2}, n_{e}, n_{0}$ being the extraordinary and ordinary refractive indices. We study only the cases, when $n_{e}>n_{0}$.

We choose the coordinate system so, that the cell plane coincides with the $\mid \underline{x}, \underline{y} /$ plane /vertical plane/, and the L director is parallel with the $\underline{z}$ axis, $\underline{\underline{L}} \| \underline{z}$. The light beam has a polarization in the $\underline{x}$ direction /in the horizontal plane/ falling perpendicularly on the cell, so the propagation vector $\mathrm{k} \| \underline{\mathrm{z}}$ and $\underline{\mathrm{L}}$.

The stationary configuration can be determined in general from the balance between the electric and elastic torques. In our case there is always a trivial solution for the balance; the unperturbed configuration, in which $\underline{L} \equiv 10,0,1 /$. To calculate the threshold we follow the usual procedure looking for the value of the light intensity at which the linearized equation of the balance of torques has a non-trivial solution.

The exact solution of the problem is very complicated. Therefore two simplifications will be used. First, we assume that the elastic constants are equal; second, the actual Gaussian transversal intensity distribution will be replaced by a $\Pi$-shape distribution.

In the one constant approximation the elastic torque is [2]

$$
\Gamma^{(e)}=K \underline{L} \times \Delta \underline{L}
$$

where $\mathrm{K}$ denotes the Frank elastic constant. The director turns in this approximation only in the $/ \underline{x}, \underline{z} /$ plane, and both the elastic and electric torque has only a $\mathrm{y}$-component.

In linear approximation the elastic torque is

$$
\Gamma \underset{y}{(e)}=k \Delta \theta
$$

with $\theta=\mathrm{L}_{\mathrm{x}}$; while the electric torque can be given as

$$
\Gamma_{y}^{(E)}=\varepsilon_{0} \varepsilon_{a} E_{x} / O E_{x}+E_{z} l
$$

$E_{X}$ is determined by the continuity of the tangential component of $\underline{E}$; $E_{x}=E_{0}$, where $E_{0}$ is the electric vector of the incoming light beam. $E_{z}$ can be calculated from the condition $D_{z}=0$, which leads to

$$
E_{z}=-\frac{\varepsilon_{a}}{\dot{n}_{e}^{2}} \theta E_{x}
$$


With the above values of $E_{z}$ and $E_{x}$ we get

$$
\Gamma \underset{y}{(E)}=\varepsilon_{0} \varepsilon_{a} \frac{n_{\circ}^{2}}{n_{e}^{2}} E_{o}^{2} \theta .
$$

The linearized equation of torques is

$$
K \Delta \theta+\varepsilon_{o} \varepsilon_{a} \frac{n_{o}^{2}}{n_{e}^{2}} E_{o}^{2} \theta=0 .
$$

Taking into account that $\mathrm{E}_{\mathrm{O}}$ is only a function of the distance $r$ from the centre of the laser beam, $\theta$ can be written as

$$
\theta|r, z|=\theta_{0}|r| \sin \frac{\pi}{l} z
$$

I $\ell$ denotes the sample thickness/, where $\theta_{0}$ obeys the equation

$$
\frac{\partial^{2} \Theta_{0}}{\partial r^{2}}+\frac{1}{r} \frac{\partial \theta_{0}}{\partial r}+\left[\frac{\varepsilon_{0} \varepsilon_{a}}{K} \frac{n_{0}^{2}}{n_{e}^{2}} E_{0}^{2}|r|-\left(\frac{\pi}{l}\right)^{2}\right] \theta_{0}=0
$$

In the actual experiments $\mathrm{E}_{0}^{2}|\mathrm{r}|$ is a Gaussian function:

$$
\begin{gathered}
E_{0}^{2}|r|=e^{2} \exp \left(-r^{2} / r_{0}^{2}\right) . \\
E_{0}^{2}|r|= \begin{cases}e^{2} & r<r_{0} \\
0 & r>r_{0}\end{cases}
\end{gathered}
$$

where $r_{0}$ is an "effective" radius of the laser beam./ The connection between $r_{0}$ and the full width of the beam at half maximum $/$ FWHM $/, \delta=2(\ln 2)^{1 / 2} r_{0} \cdot /$ In this case the non-trivial solution of Eq. $/ 1 /$ with boundary conditions $\theta_{0} \mid 0 /=1, \theta_{0}^{\prime} / 0 /=0$ and $\theta_{0} \rightarrow 0$ for $r \rightarrow \infty$ is

$$
\theta_{0}|r|= \begin{cases}J_{0}|\lambda r| & r<r_{0} \\ a K_{0} / \mu r \mid & r>r_{0}\end{cases}
$$

where $J_{\circ}$ and $\mathrm{K}_{\mathrm{o}}$ denote the O-order Bessel and modified Hankel functions resp. [3] and

$$
\lambda^{2}=e^{2} \frac{\varepsilon_{0} \varepsilon_{a}}{K} \frac{n_{o}^{2}}{n_{e}^{2}}-\left(\frac{\pi}{l}\right)^{2} ; \mu=\frac{\pi}{l} .
$$


$\lambda$ can be determined from the condition, that both $\theta_{0}$ and $\frac{\partial \theta_{0}}{\partial r}$ should be continuous at $r_{0}$. This condition leads to

$$
\gamma \frac{J_{0}^{\prime}(\gamma)}{J_{0}(\gamma)}=\kappa \frac{\kappa_{0}^{\prime}(k)}{K_{0}(k)}
$$

with $\gamma=\lambda r_{0}, k=\mu r_{0}=\pi \frac{r_{0}}{l}$. The solution of Eq. $12 /$ is given in Fig. 1 .

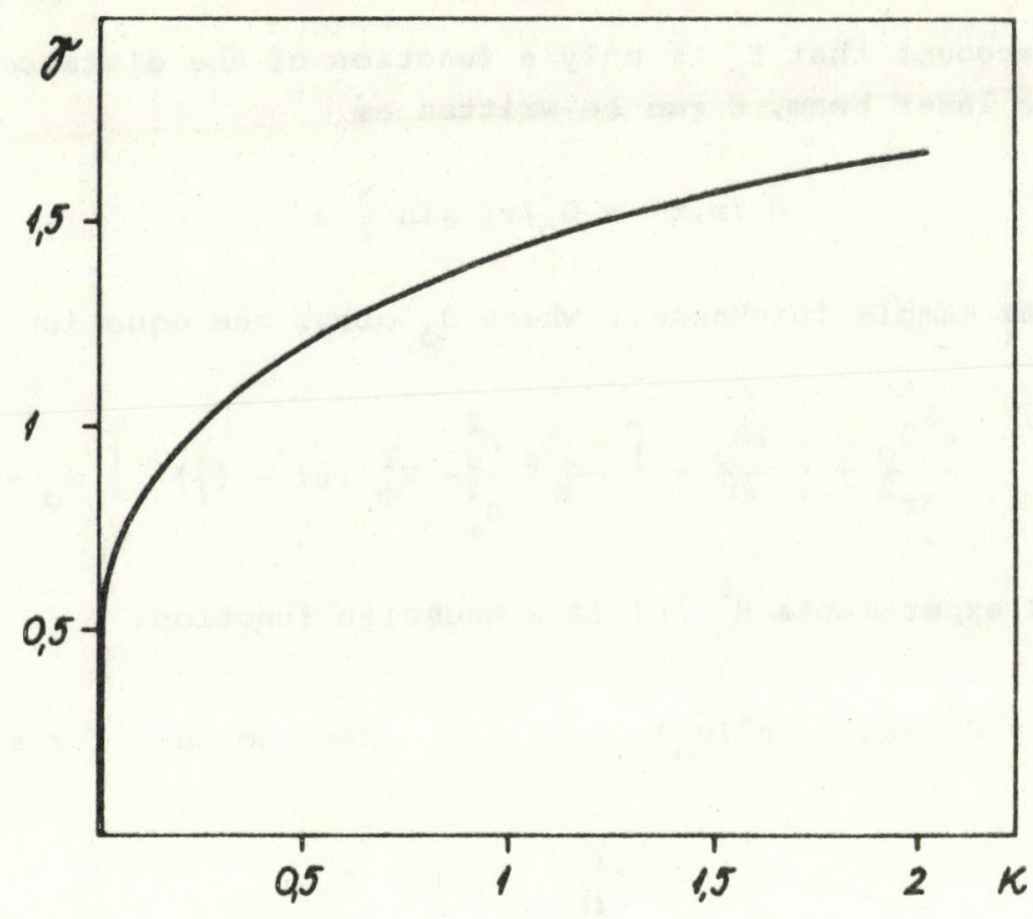

Fig. 1. The solution of Eq. /2/

The power of the light beam is

$$
\mathrm{P}=\frac{\mathrm{c} \mathrm{r}_{\mathrm{o}}^{2 \pi}}{\varepsilon_{\mathrm{o}}} e^{2} / \mathrm{c} \text { light velocity/. }
$$

The threshold power therefore can be written as

$$
\begin{gathered}
P_{t h}=P_{0}\left(\gamma^{2}(k)+k^{2}\right) \text { with } \\
P_{0}=\frac{c \pi K}{n_{e}^{2}-n_{0}^{2}} \frac{n_{e}^{2}}{n_{0}^{2}} .
\end{gathered}
$$

In Fig. $2, \mathrm{P}_{\text {th }} / \mathrm{P}_{0}$ is $\mathrm{given}$ as a function of $\mathrm{r}_{\mathrm{o}} / \ell /$ full line/. The dashed line 


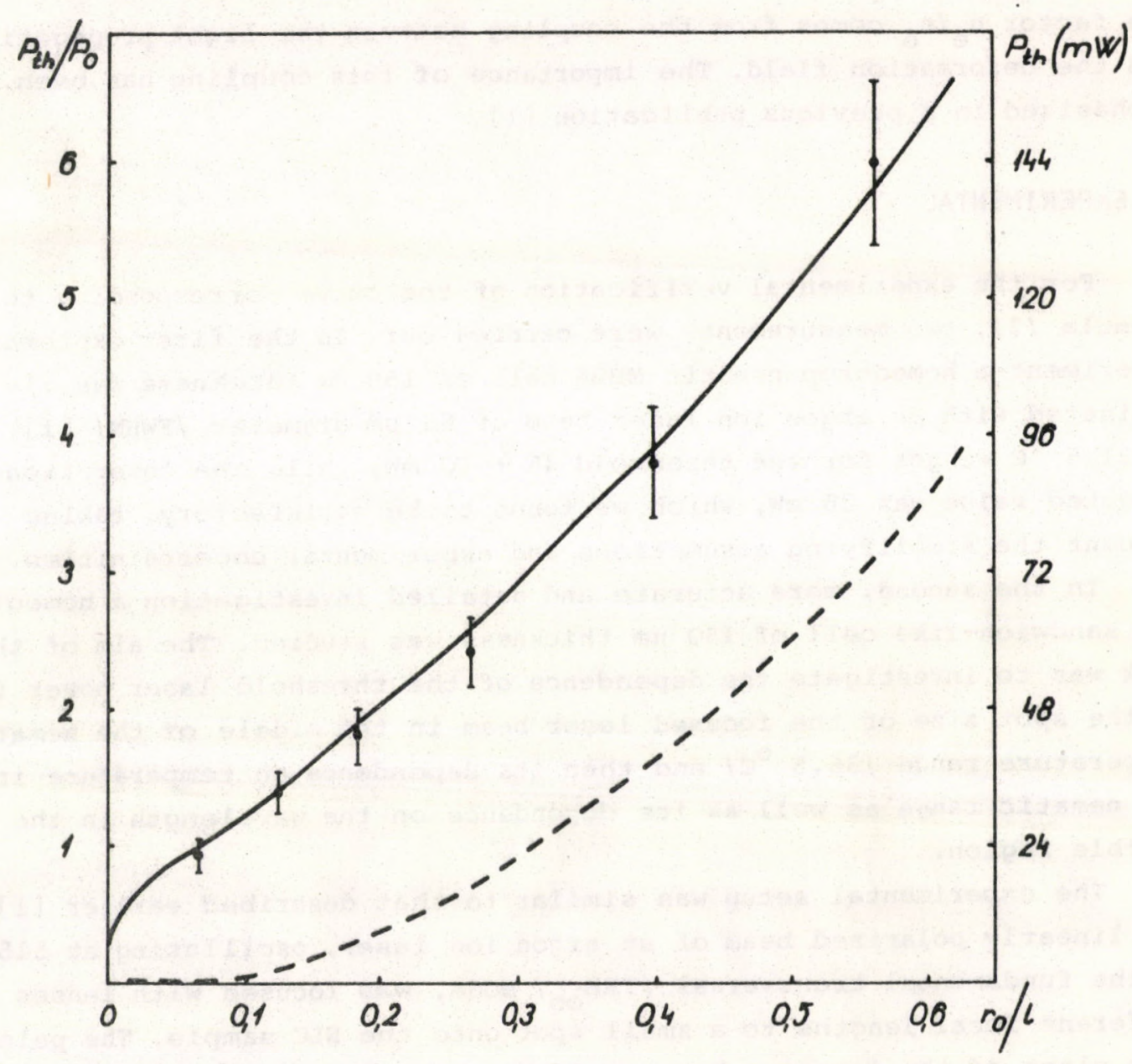

Fig. 2. Full line: $P_{t h} / P_{0}$ as a function of $r_{0} / l$ according to our model. Dashed line: the power corresponding to the Fredericks threshold formula. The experimental points were measured on ОСВ at $36.5^{\circ} \mathrm{C}$; the power scale for this measurement is given at the right hand side of the figure. A good agreement between theory and experiment is obtained with $P_{0}=24 \mathrm{~mW}$.

on this figure gives the threshold, if we apply simply the Fredericks threshold formula $\epsilon_{t h}=\frac{\pi}{\ell}\left(\frac{K}{\varepsilon \varepsilon}\right)^{1 / 2}$. The difference between the two curves is remarkable. The ratio of the two thresholds goes to infinity as $r_{0} / l \rightarrow 0$. Therefore we can conclude, that it is very important to take into account the finite radius of the laser beam.

It is interesting to note that even for very large $r_{0} / \ell$ values $e_{t h}$ does not reduce to the usual Fredericks formula. In this limit

$$
e_{\text {th }}=\frac{n_{e}}{n_{0}} \frac{\pi}{\ell}\left(\frac{k}{\varepsilon_{0} \varepsilon_{a}}\right)^{1 / 2} \quad\left(r_{0} / \ell \rightarrow \infty\right) .
$$


The factor $n_{e} / n_{0}$ comes from the coupling between the light propagation and the deformation field. The importance of this coupling has been emphasized in a previous publication [ $L$.

\section{EXPERIMENTAL}

For the experimental verification of the curve corresponding to the formula $13 /$, two measurements were carried out. In the first exploratory experiment a homeotrop nematic MBBA cell of $150 \mu \mathrm{m}$ thickness was illuminated with an argon ion laser beam of $65 \mu \mathrm{m}$ diameter /FWHM/ [1]. At $21,5{ }^{\circ} \mathrm{C}$ we got for the threshold $45 \pm 10 \mathrm{~mW}$, while the theoretically expected value was $35 \mathrm{~mW}$, which we found to be satisfactory, taking into account the simplifying assumptions and experimental uncertainities.

In the second, more accurate and detailed investigation a homeotropic OCB sandwich-like cell of $150 \mu \mathrm{m}$ thickness was studied. The aim of this work was to investigate the dependence of the threshold laser power first on the spot size of the focused laser beam in the middle of the nematic temperature range $136,5^{\circ} \mathrm{C} /$ and then its dependence on temperature in the nematic range as well as its dependence on the wavelength in the visible region.

The experimental setup was similar to that described earlier [1]. The linearly polarized beam of an argon ion laser, oscillating at $515 \mathrm{~nm}$ in the fundamental transversal /TEM ${ }_{0 O} /$ mode, was focused with lenses of different focal lengths to a small spot onto the NLC sample. The polarization plane of the incoming beam could be changed with the aid of a polarization rotator/Spectra Physics Model 310-21/. The cell consisted of two circular glass plates separated with a teflon spacer of $150 \mu \mathrm{m}$ thickness and sealed off with an epoxy resin. The homeotropic alignment was achieved by treating the glass surfaces with a weak solution of CTAB in chloroform [4]. The alignment was carefully tested with the conoscopic method. The normal incidence of the beam was adjusted carefully with the aid of the spot reflected from the cell boundaries.

The laser power was measured with a Spectra Physics power meter /Model 404/, which had a calibration accuracy of $\pm 15 \%$. Our power values refer always to the plane of the NLC sample i.e. the reflection losses on the lens and windows are taken into account. The intensity stability of the laser was better than $0,5 \%$.

For focusing the laser beam, six lenses with different focal lengths $17,5+50 \mathrm{~cm} /$ and of different quality were used. The lenses were always carefully adjusted for paraxial beam propagation. At a given lens, the minimal beam diameter of the focused beam could be determined with the effect itself; at a constant laser power the lens position was changed 
t111 the maximal number of fringes could be observed.

The intensity distribution in the sample plane was scanned with a pinhole of $5 \mathrm{\mu m}$ diameter mounted on a linear stage, which could be moved across the beam with an accuracy of $\pm 0,2 \mu \mathrm{m}$. In all cases we got a nearly Gaussian intensity distribution. Some examples are given in Fig. 3 .

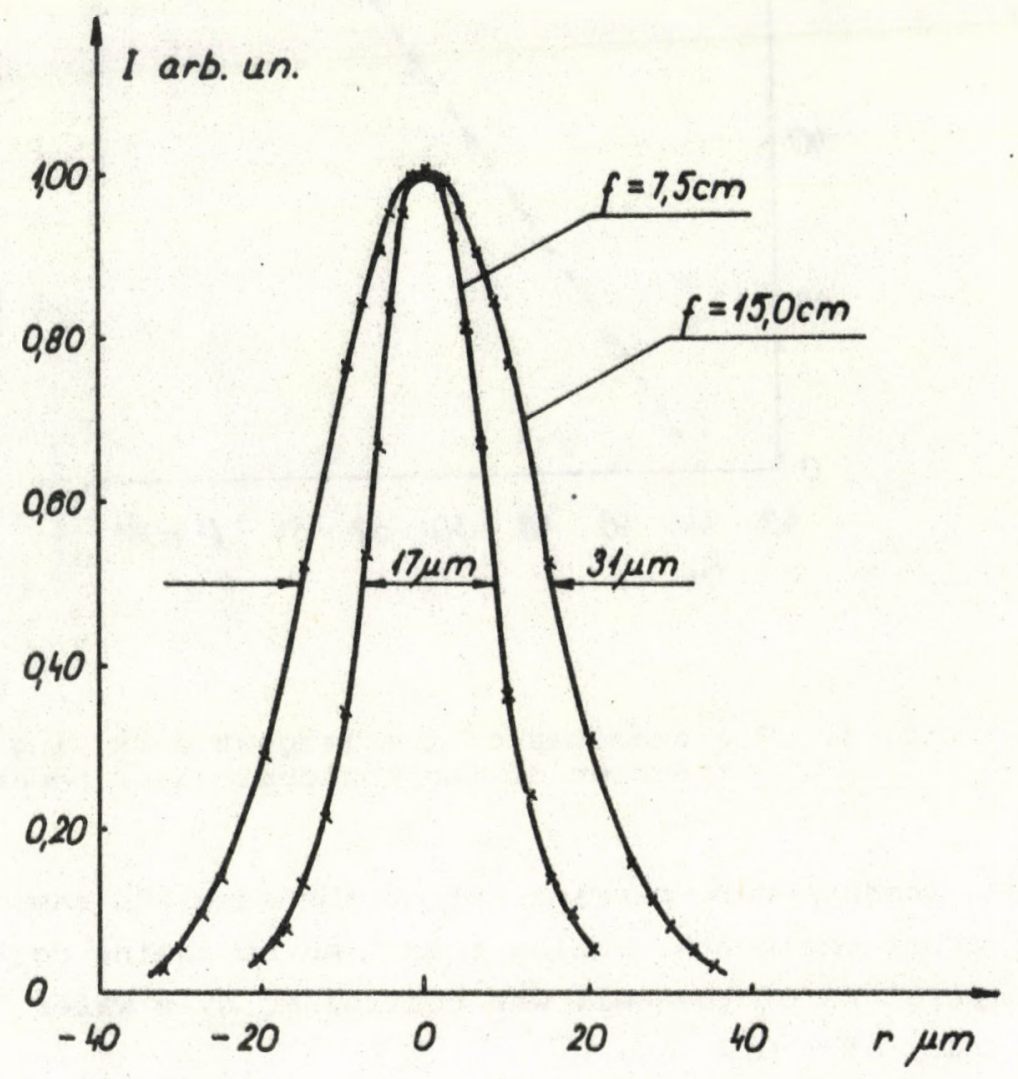

Fig. 3. Intensity distribution of the laser beam at the sample with different lenses.

It should be mentioned here that according to the laser beam propagation laws [5], the size of the focused beam near its minimum changes very slowly; in our case, over the $150 \mu \mathrm{m}$ thickness of the ce11, the variation of the beam diameter was less than 1 \& even for the lens of shortest focal length $/ \mathrm{f}=7,5 \mathrm{~cm} /$.

For determining the threshold, the diameter of the largest dark ring, observed in the transmitted beam on a screen was measured as a function of the incident laser power; this dependence proved to be nearly linear below 10 rings /Fig. $4 /$. We defined the threshold as the intersection point of this line with the power axis. 


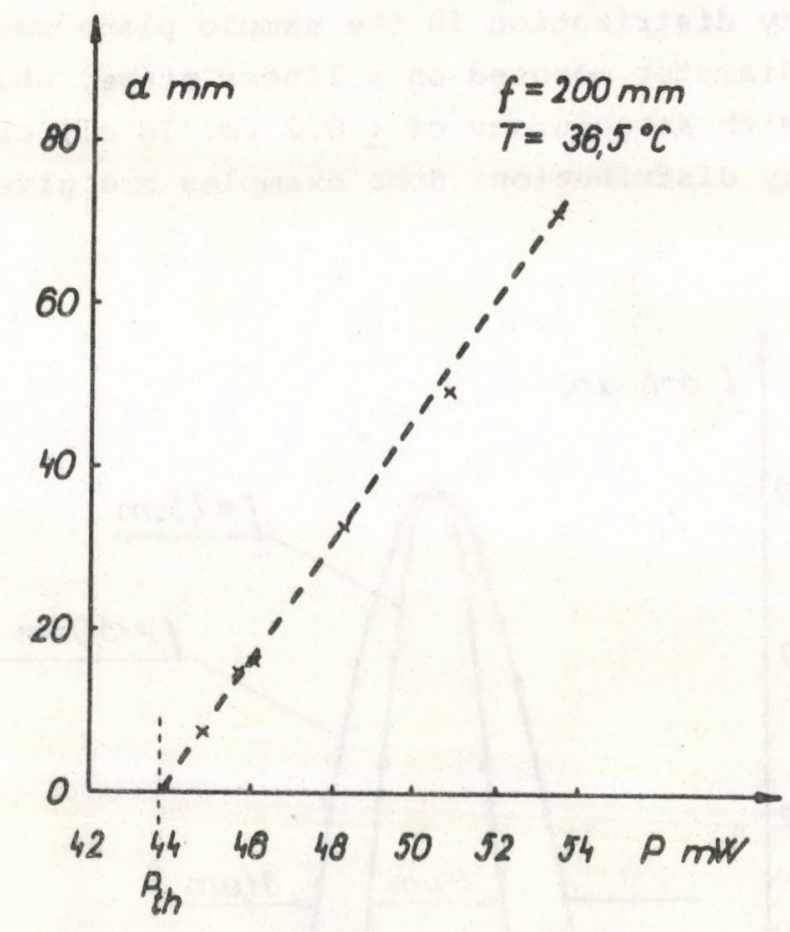

Fig. 4. The diameter of the largest dark ring as a function of the incident laser power.

All measurements were carried out on the same OCB sample, in a time interval of about one month. During this time no ageing could be observed.

The temperature of the cell was controlled by a water thermostat, with an accuracy of $\pm 0,2^{\circ} \mathrm{C}$.

At each measuring point, after starting the illumination we waited till the pattern had stabilized; this some times lasted at low power levels about 10-15 minutes. Between two measurements there was always a 1-2 minutes pause to avoid memory effects. The measurements were carried out repeatedly, at different places of the cell and with different planes of polarization of the incident beam. Places with the smallest diffuse light scattering were always chosen. The results measured under different conditions commonly did not differ more than a few mw. The spread amounted $\pm 2 \mathrm{~mW}$ with the lens $\mathrm{f}=15 \mathrm{~cm}$ and $\pm 5 \mathrm{mw}$ with that of $30 \mathrm{~cm}$ focus resp., i.e. the statistical error in our measurement was $\pm 10 \%$. It should be noted, that there may still be an additional systematic error of \pm 15 \& due to the calibration accuracy of the power meter, which could be the main source of the error in $P_{0}$ and especially in the wavelength dependence of $\mathrm{P}_{\text {th }}$. 


\section{RESULTS}

The threshold intensity was measured as a function of the spot size at a fixed temperature $136,5^{\circ} \mathrm{C} /$. The experimental data are given in Fig. 1. A good agreement between the theoretical curve and the experimental data is found with $\mathrm{P}_{\mathrm{O}}=24 \mathrm{~mW}$.

The theoretical expression for $P_{0}$, given by Eq. $/ 3 /$ contains the material parameters of the nematic. In the actual case $P_{0}$ can be determined however only with a certain arbitrariness, because our theoretical model assumes that the elastic constants are equal, while in reality they are different. Therefore, to compare the theoretical and experimental values, we invert Eq. /3/ and evaluate an "effective" elastic constant from the threshold value. Using the experimental data of Karat et. al. [6] $\mathrm{n}_{e}=1,678, \mathrm{n}_{\mathrm{o}}=1,533136,5{ }^{\circ} \mathrm{C}, \lambda=515 \mathrm{~nm}$ extrapolated from 546 and $589 \mathrm{~nm} /$ and taking $\mathrm{P}_{0}=24 \mathrm{~mW}$ 'we get

$$
\mathrm{K}_{\text {eff }}=/ 1,0 \pm 0,15 / \times 10^{-11} \mathrm{~N}
$$

According to Karat et al. [7] the actual values of the elastic constants at this temperature are:

$$
\mathrm{K}_{1}=1,07 \times 10^{-11} \mathrm{~N} ; \mathrm{K}_{2}=0,45 \times 10^{-11} \mathrm{~N} ; \quad \mathrm{K}_{3}=1,05 \times 10^{-11} \mathrm{~N} \text {. }
$$

Thus $\mathrm{K}_{\text {eff }}$ is comparable with the elastic constants measured independently; its value is very near to $\mathrm{K}_{1}$ and $\mathrm{K}_{3}$.

In further experiments the temperature and wavelength dependence of the threshold was measured at a fixed spot size. The temperature dependence of the threshold was determined at $r_{0}=18,6 \mu \mathrm{m}$. The results are given in Table I. In Fig. 5, the effective elastic constant, determined from the

\section{TABLE I}

Temperature dependence of laser threshold

If $=150 \mathrm{~mm}$, ОСB homeotrop cell. $\ell=150 \mu \mathrm{m}$, normal incidence, $\lambda=515 \mathrm{~nm} /$

\begin{tabular}{|r|r|r|r|r|r|r|}
\hline$t{ }^{\circ} \mathrm{C}$ & 34,0 & 34,4 & 34,8 & 36,3 & 38,0 & 39,4 \\
\hline $\mathrm{P}_{\mathrm{th}} \mathrm{mW}$ & 51,0 & 43,5 & 38,0 & 34,0 & 29,0 & 24,5 \\
\hline
\end{tabular}




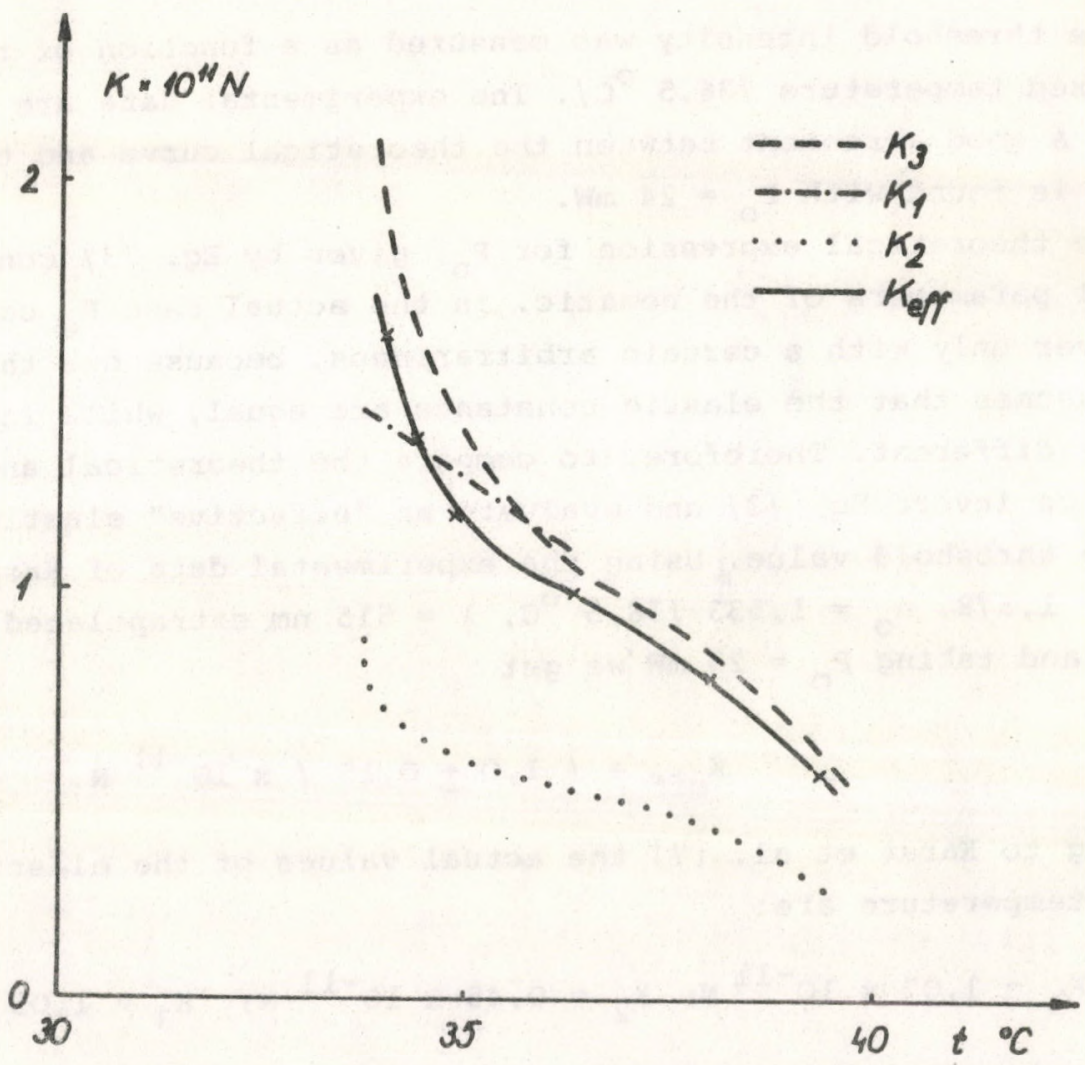

Fig. 5. The effective elastic constant as a function of the temperature /full line/. For comparison the elastic data of Karat and Madhusudana [7] are presented also.

thresholds is plotted against the temperature. For comparison the elastic data of Karat et al. [7] are presented in the same figure. As it can be seen, the effective elastic constant is in the whole temperature range near to $\mathrm{K}_{1}$ and $\mathrm{K}_{3}$ and it shows a pretransitional increase below $35^{\circ} \mathrm{C}$. This increase can be evidently attributed to the sharp increase of $\mathrm{K}_{2}$ and $\mathrm{K}_{3}$ in the same temperature region.

The wavelength dependence of the threshold was investigated by comparing the thresholds for $515 \mathrm{~nm}$ /a green line of the argon laser/ with that for two different wavelengths: for a blue line of the same argon ion laser $/ 476 \mathrm{~nm} /$ and for the red line of an He-Ne laser $/ 633 \mathrm{~nm} /$ :

In the case of the blue line, the measured threshold, with a spot diameter of $30 \mu \mathrm{m} / \mathrm{f}=15 \mathrm{~cm}$ lens $/$ and at 36,5 ․ temperature:

$$
\mathrm{P}_{\text {th }} / 476 \mathrm{~nm}, 30 \mu \mathrm{m}, 36,5^{\circ} \mathrm{C} /=\mid 31,2 \pm 4 / \mathrm{mW} \text {, }
$$


For $515 \mathrm{~nm}$ :

$$
\mathrm{P}_{\text {th }} / 515 \mathrm{~nm}, 30 \mu \mathrm{m}, 36,5^{\circ} \mathrm{C} /=/ 33 \pm 4 / \mathrm{mW}
$$

In the case of the red He-Ne laser, higher temperature and lens with the shortest focus $/ \mathrm{f}=7,5 \mathrm{~cm} / \mathrm{had}$ to be used due to the smaller power available. We found with a spot diameter of $27 \mu \mathrm{m}$ and at $38^{\circ} \mathrm{C}$ :

$$
P_{\text {th }} / 633 \mathrm{~nm}, 27 \mu \mathrm{m}, 38^{\circ} \mathrm{C} /=/ 25,6 \pm 4 / \mathrm{mW} \text {, }
$$

while for $515 \mathrm{~nm}$ :

$$
\mathrm{P}_{\text {th }} / 515 \mathrm{~nm}, 27 \mu \mathrm{m}, 38^{\circ} \mathrm{C} /=126 \pm 4 / \mathrm{mW} .
$$

In both cases the thresholds proved to be practically the same.

The theoretical formula, Eq. /3/ predicts a very slow variation of $P_{\text {th }}$ with the wavelength, i.e. as

$$
\frac{n_{e}^{2}}{n_{0}^{2}}\left(n_{e}^{2}-n_{0}^{2}\right)^{-1}
$$

changes with $\lambda$. These small changes, however are well inside the experimental error and we can conclude, that the observed very weak dependence on the wavelength gives additional support to our interpretation of the effect.

5. SUMMARY

In the paper we described a simple theoretical model of the Fredericks transition induced by optical fields. This model predicts the threshold intensity as a function of the spot size of the laser beam. The experimental data fit well the theoretical curve. From the fitting parameter, $\mathrm{P}_{\mathrm{O}}$, an "effective" elastic constant was determined, which turned out to be for ОСB near to the bend and splay elastic constants. The temperature dependence of $\mathrm{K}_{\mathrm{eff}}$ followed well the temperature dependence of $\mathrm{K}_{3}$; in particular the same pretransitional increase was found near to the nematic- smectic A transition. The wavelength dependence of the threshold was found to be weak, in agreement with the theory.

In conclusion, the theoretical model explains the main features of the experimental observations and provides a reliable numerical value for the threshold. This proves the underlying idea, i.e. that the observed phenomena is due to a Fredericks transition in optical field, which can be described by the continuum theory of nematics, taking into account the finite size of the deforming light beam. 
The theory, used here involves two simplifications. First, it assumes a $\Pi$ shape instead of a Gaussian. This approximation could be overcome by some numerical calculation; it is however coubtfull whether this would be worthwhile if at the same time the second simplification, the one constant approximation were maintained.

The theory becomes much more complicated if the elastic constants are not assumed to be equal. As it can be shown, if $K_{1} \neq K_{2}$ the cylindrical symmetry of the deformation is lost. Furthermore in this case the $\theta$ variable is not sufficient to describe the deformation, because the director should have an $y$-component too. In addition the coupling between the electromagnetic wave and the director field becomes more complicated in the presence of such deformation. All these circumstances cause considerable mathematical difficulties. On the other hand they may give rise to some original features in the cases of circularly polarised light beam or slightly oblique incidence, which cannot be described by our simplified model. Further work is planned in this direction.

\section{REFERENCES}

[1] L. Csillag, I. Jánossy, V.F. Kitaeva, N. Kroó, N.N. Sobolev and A.S. Zolotko: to be published in Mol. Cryst. Liq. Cryst.

[2] P.G. de Gennes: The Physics of Liquid Crystals. Clarendon Press, Oxford, 1974 .

[3] Janke-Emde-Lösch: Tafeln höherer Funktionen. B.G. Teubner Verlagsgese11schaft. Stuttgart, 1960.

[4] J.E. Proust and L. Ter-Minassian-Saraga: Solid State Comm. 11 , $1227 / 1972 /$

[5] H. Kogelnik and T. Li : Proc IEEE 54, $1312 / 1966 /$

[6] P.P. Karat and N.V. Madhusudana: Mol. Cryst. Liq. Cryst. 36, 51 /1976/

[7] P.P. Karat and N.V. Madhusudana: Mol. Cryst. Liq. Cryst. 40, 239 /1977/ 





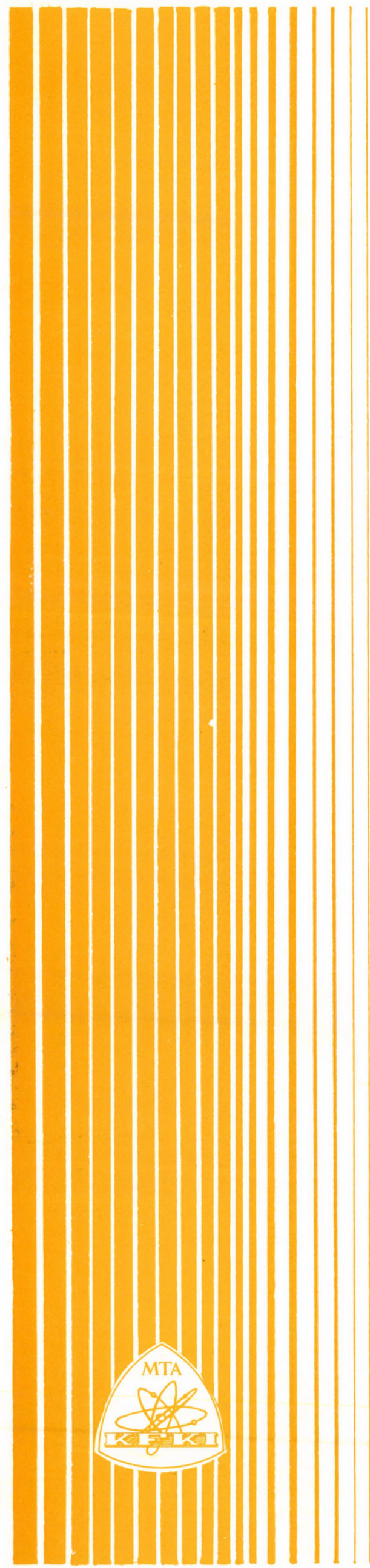

Kiadja a Központi Fizikai Kutató Intézet Felelõs kiadó: Kroó Norbert

Szakmai lektor: Eber Nándor Nyelvi lektor: Jánossy Mihály Gépelte: Nagy Imréné

Példányszám: 570 Törzsszám: 81-484 Készült a KFKI sokszorositó üzemében Felelôs vezetõ: Nagy Károly

Budapest, 1981. szeptember hó 